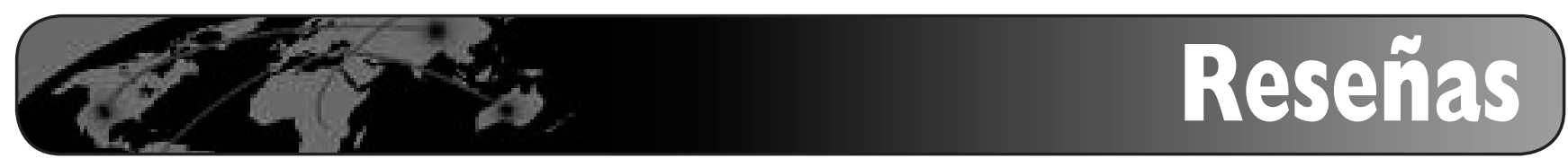

\title{
Cine en la era digital: aplicaciones de la documentación cinematográfica (Alfonso López Yepes, director)
}

\author{
Por Lluís Codina
}

\begin{abstract}
Codina, Lluís. "Cine en la era digital: aplicaciones de la documentación cinematográfica (Alfonso López Yepes, director)". Reseña de libro. En: El profesional de la información, 2007, marzo-abril, v. 16, n. 2, pp. 169-170.

DOI: 10.3145/epi.2007.mar.14
\end{abstract}

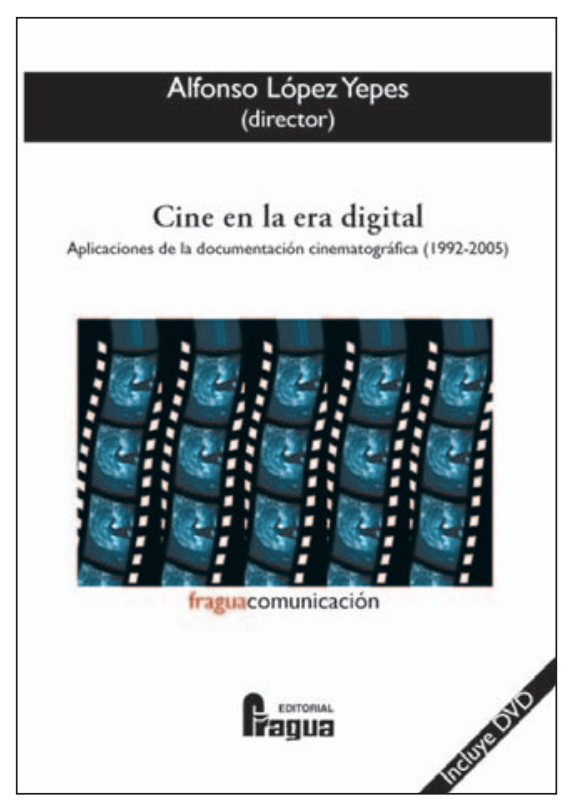

LA DOCUMENTACIÓN CINEMATOGRÁFICA posee un estatus curioso: su importancia en el proceso de producción del film, primero, $y$ en la investigación, conservación y difusión del cine, después, es enorme.

A la vez, como sabemos, el cine es una manifestación cultural (y política) de primer orden y de las de mayor impacto mediático. Por tanto podríamos decir que la documentación cinematográfica está en el centro del centro: en el centro de una industria cultural que está, a su vez, en el centro de la cultura. Pues bien, pese a ello, lo cierto es que suele padecer de un cierto "estatus de transparencia" porque es una especialidad que en ocasiones nos pasa inadvertida.
Afortunadamente, no siempre es así, ni mucho menos. De ello se ocupa con feliz obstinación el catedrático de la Universidad Complutense de Madrid Alfonso López Yepes. En esta ocasión su recordatorio de que "la documentación cinematográfica también existe" adopta la forma de una muy oportuna obra que reúne trabajos, experiencias y proyectos que abarcan una década y media, exactamente desde 1992 hasta 2005.

Se trata de una obra de compilación que une en solo volumen trabajos que tratan sobre diversos aspectos de la documentación cinematográfica del propio Alfonso López Yepes y de otros tres autores: Elena de la Cuadra, Rodrigo Sánchez y José Ramón Pérez. En total el libro ofrece 12 trabajos que los mencionados autores han ido publicando a lo largo de la época señalada (19922005), y que han articulado en torno a siete apartados:

- Archivos fílmicos, filmotecas, centros de documentación

1. Usuarios de documentación cinematográfica.

- Software para la producción audiovisual y cinematográfica.

- Movie magic scheduling: estructura y aplicaciones.

- Tratamiento de la documentación audiovisual y cinematográfica en el entorno digital: Iniciativas de

\section{López Yepes,} Alfonso.

Cine en la era digital: aplicaciones de la documentación cinematográfica (1992-2005). Madrid: Fragua, 2006, 236 pp. ISBN 84-7074-202-7

metadatos y lenguajes de descripción multimedia.

2. Bases de datos - Fuentes de información.

- Enciclopedia del cine español: Una publicación interactiva en soporte óptico.

- Bancos de imágenes en internet.

- CineDocNet - TVDocNet: Una comunidad virtual de usuarios de documentación audiovisual (cinematográfica y televisiva).

- CineDocNet: Portal universitario español de documentación e investigación cinematográfica multimedia en línea.

\section{Cine en la era digital.}

- Documentación cinematográfica: El cine en la era digital.

\section{Cine en internet.}

- Cine y fuentes de información en 
internet: Panorámica documental y repertorio básico de sitios web.

5. Enseñanza - Formación - Investigación.

- La enseñanza multimedia de la documentación cinematográfica.
6. Industria - Financiación.

- Comisiones fílmicas en línea.

7. Estudios documentales.

- Documentación en "Cuéntame".

Lo cierto es que la propia articulación de la obra o, dicho de otro modo, la enumeración de los rótulos de cada apartado y de sus capítulos proporciona una idea, por un lado de la riqueza intrínseca de esta especialidad y, por otro lado, de la diversidad de enfoques e intereses vinculados con la documentación cinematográfica que abarca el libro.

Dos cuestiones más antes de ir cerrando esta reseña. Destaca en toda la obra una característica que es, en realidad, muy propia del coordinador de la misma, a saber:

- una clara voluntad de servicio a los profesionales y estudiosos

\section{¿Recibes ya E P I en casa?}

Por sólo 75 euros $+$ 4\% IVA

puedes tener todos los meses tu copia particular y leerla cómodamente cuando quieras.

de la materia aportando claves, tendencias y datos e informaciones de referencia. De hecho, si unimos la lista de centenares de publicaciones y de sitios web mencionados a lo largo de todos los capítulos tendremos una compilación difícil de superar en esta materia.

Por último, el libro se acompaña de un DVD que contiene el propio libro en formato pdf y algo más de cien vídeos que totalizan 1,5 GB de material audiovisual. La mayor parte de los vídeos consisten en filmaciones de conferencias, entrevistas o mesas redondas y congresos que complementan los diversos temas abordados en la obra.

\section{Lluís Codina}

lluis.codina@upf.edu

\section{Acceso abierto}

La publicación de "El profesional de la información" es posible gracias a las cuotas de los suscriptores y a los anuncios de las empresas, sin embargo la editorial apoya el movimiento open access e invita a todos los autores a que depositen los textos completos de sus trabajos publicados en EPI en el repositorio E-LIS:

\section{http://eprints.rclis.org/}

Para ello el único requisito exigido es que citen la web de EPI como lugar alternativo donde consultar los artículos:

\section{http://www.elprofesionaldelainformacion.com/}

